\title{
Maturation of the Na,K-ATPase in the Endoplasmic Reticulum in Health and Disease
}

\author{
Vitalii Kryvenko ${ }^{1,2} \cdot$ Olga Vagin $^{3,4} \cdot$ Laura A. Dada $^{5} \cdot$ Jacob I. Sznajder $^{5} \cdot$ István Vadász $^{1,2} \mathbb{C}$
}

Received: 19 March 2021 / Accepted: 8 May 2021 / Published online: 10 June 2021

(c) The Author(s) 2021

\begin{abstract}
The Na,K-ATPase establishes the electrochemical gradient of cells by driving an active exchange of $\mathrm{Na}^{+}$and $\mathrm{K}^{+}$ions while consuming ATP. The minimal functional transporter consists of a catalytic $\alpha$-subunit and a $\beta$-subunit with chaperon activity. The Na,K-ATPase also functions as a cell adhesion molecule and participates in various intracellular signaling pathways. The maturation and trafficking of the Na,K-ATPase include co- and post-translational processing of the enzyme in the endoplasmic reticulum (ER) and the Golgi apparatus and subsequent delivery to the plasma membrane (PM). The ER folding of the enzyme is considered as the rate-limiting step in the membrane delivery of the protein. It has been demonstrated that only assembled Na,K-ATPase $\alpha: \beta$-complexes may exit the organelle, whereas unassembled, misfolded or unfolded subunits are retained in the ER and are subsequently degraded. Loss of function of the Na,K-ATPase has been associated with lung, heart, kidney and neurological disorders. Recently, it has been shown that ER dysfunction, in particular, alterations in the homeostasis of the organelle, as well as impaired ER-resident chaperone activity may impede folding of Na,K-ATPase subunits, thus decreasing the abundance and function of the enzyme at the PM. Here, we summarize our current understanding on maturation and subsequent processing of the Na,K-ATPase in the ER under physiological and pathophysiological conditions.
\end{abstract}

István Vadász

istvan.vadasz@innere.med.uni-giessen.de

1 Department of Internal Medicine, Universities of Giessen and Marburg Lung Center (UGMLC), Member of the German Center for Lung Research (DZL), Justus Liebig University, Klinikstrasse 33, 35392 Giessen, Germany

2 The Cardio-Pulmonary Institute (CPI), Giessen, Germany

3 Department of Physiology, David Geffen School of Medicine, University of California at Los Angeles, Los Angeles, CA, USA

4 Veterans Administration Greater Los Angeles Healthcare System, Los Angeles, CA, USA

5 Division of Pulmonary and Critical Care Medicine, Feinberg School of Medicine, Northwestern University, Chicago, IL, USA 


\section{Graphic Abstract}

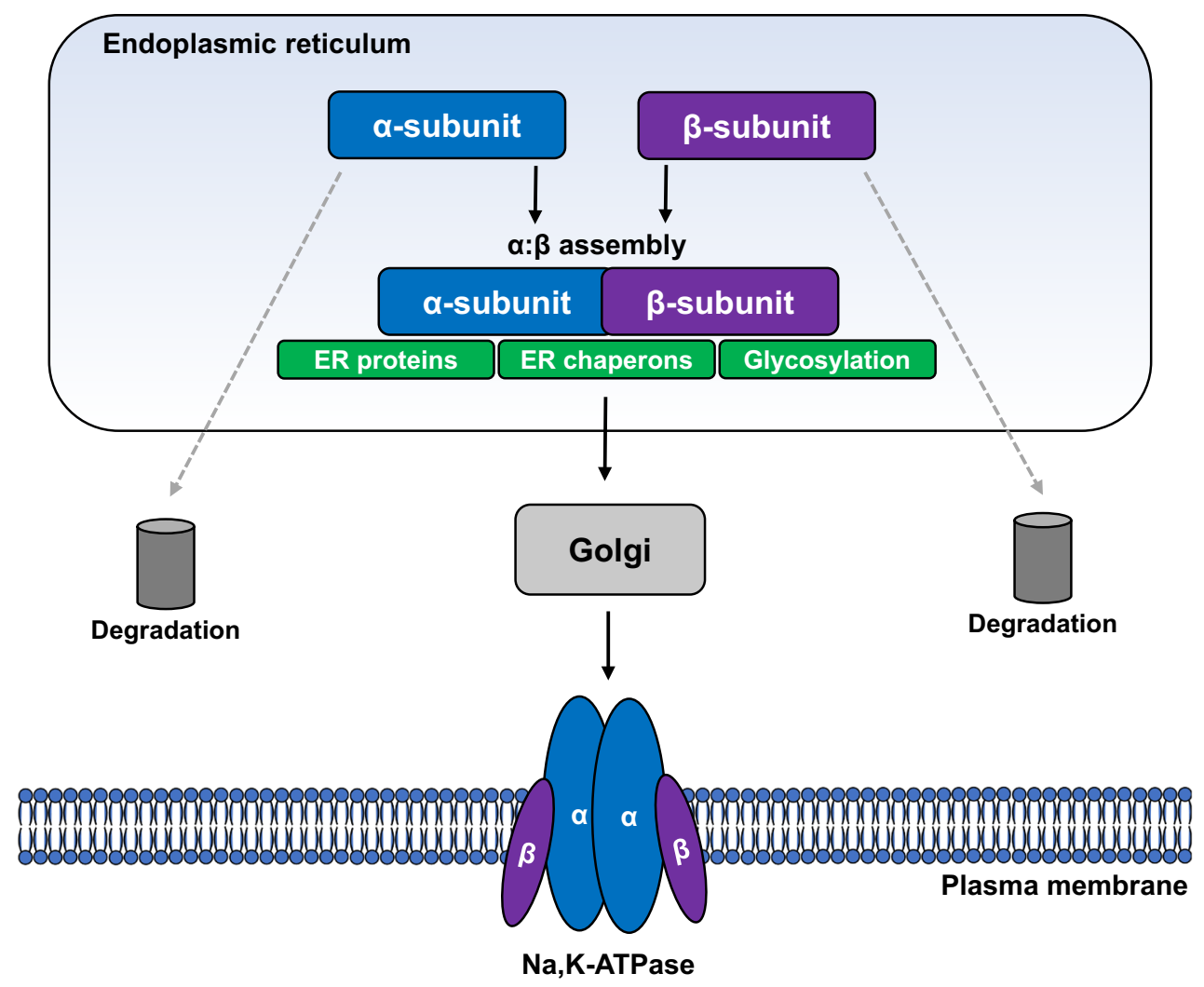

Keywords Na,K-ATPase $\cdot$ Endoplasmic reticulum $\cdot$ Protein maturation $\cdot$ Protein folding $\cdot$ Unfolded protein response

\section{Function, Structure and Regulation of the $\mathrm{Na}$,K-ATPase}

The Na,K-ATPase that is widely expressed in various tissues and organs is a heterodimeric enzyme and a member of the P-type ATPase family (Jorgensen et al. 2003; Kaplan 2002). In polarized cells, the Na,K-ATPase is localized at the basolateral membrane, where the transporter performs its primary function, establishment of a $\mathrm{Na}^{+} / \mathrm{K}^{+}$gradient, which is achieved by pumping three $\mathrm{Na}^{+}$ions out of the cell in exchange to two $\mathrm{K}^{+}$ions while hydrolyzing a single ATP molecule. This activity of the Na,K-ATPase consumes up to $50-70 \%$ of total cellular ATP (Wieser and Krumschnabel 2001). The above-mentioned ion gradients are not only important for movement of $\mathrm{Na}^{+}$and $\mathrm{K}^{+}$across the cell, but also play an essential role in secondary active transport of ions $\left(\mathrm{H}^{+}, \mathrm{Ca}^{2+}, \mathrm{Cl}^{-}\right)$, amino acids, sugars and neurotransmitters (Jorgensen et al. 2003; Kaplan 2002). Furthermore, ion gradients generated by the Na,K-ATPase are essential to control cell volume and to restore the resting membrane potential in excitable cells (Lingrel 2010; Yordy and Bowen 1993). In addition to ion transport, the Na,K-ATPase also acts as a cell adhesion molecule in polarized epithelial cells (Cereijido et al. 2012; Vagin et al. 2012), indirectly regulates permeability of tight junctions by leading to hyperphosphorylation of occludin (Rajasekaran et al. 2007), controls the actin cytoskeleton, cellular volume and motility (Rajasekaran et al. 2001a, b). Moreover, the Na,K-ATPase participates in various intracellular signaling pathways by indirectly regulating $\mathrm{Ca}^{2+}$ concentrations (Tian and Xie 2008) and responds to oxidative stress (Figtree et al. 2012; Huang et al. 1994; Liu et al. 2012; Pratt et al. 2018).

The minimal functional Na,K-ATPase molecule consists of a catalytic $\alpha$ - and a $\mathrm{N}$-glycosylated $\beta$-subunit.(Morth et al. 2009). As reviewed recently, four isoforms of the $\alpha$-subunits $\left(\alpha_{1}, \alpha_{2}, \alpha_{3}\right.$ and $\left.\alpha_{4}\right)$ and three isoforms of the $\beta$-subunits $\left(\beta_{1}\right.$, $\beta_{2}$ and $\beta_{3}$ ) have been identified, of which the $\alpha_{1}: \beta_{1}$ combination is the most abundant. Of note, the heterodimeric composition of different $\alpha$ - and $\beta$-subunit isoforms is tissue-specific and modulates the kinetic properties and ion affinity of the transporter (Clausen et al. 2017).

Structurally, the Na,K-ATPase $\alpha$-subunit has a molecular mass of $\sim 110 \mathrm{kDa}$ and consists of a large intracellular domain, ten transmembrane segments, and an extracellular 
domain. In contrast to the $\beta$-subunit, the $\alpha$-subunit is tightly linked to the cellular cytoskeleton (Kaplan 2002). The $\alpha$-subunit consists of three cytoplasmic domains [A (actuator), $\mathrm{N}$ (nucleotide binding) and $\mathrm{P}$ (phosphorylation)], which are required for ATP hydrolysis, and 10 transmembrane helices, where the binding sites for $\mathrm{Na}^{+}$and $\mathrm{K}^{+}$are localized (Kanai et al. 2013; Nyblom et al. 2013). Several phosphorylation sites in the $\alpha$-subunit, e.g., $\operatorname{Tyr}^{10}, \operatorname{Ser}^{16}, \operatorname{Ser}^{18}, \operatorname{Ser}^{23}$ on the $\mathrm{N}$ terminus and $\mathrm{Ser}^{943}$ on the $\mathrm{C}$ terminus, regulate activity and internalization of the enzyme by intracellular signaling pathways (Aperia 2007; Feschenko and Sweadner 1995; Soltoff et al. 2010; Sweadner and Feschenko 2001).

The Na,K-ATPase $\beta$-subunit is a type II integral membrane protein. Depending on the glycosylation profile, it has a molecular weight of $\sim 35-55 \mathrm{kDa}$ and consists of a short $\mathrm{N}$-terminal cytoplasmic, a single transmembrane and a large extracellular domain with three $\mathrm{N}$-glycosylation sites (Tokhtaeva et al. 2011; Vagin et al. 2012). The main function of the Na,K-ATPase $\beta$-subunit is to serve as a chaperone for the $\alpha$-subunit and to coordinate its delivery to the PM (Geering 2008; Tokhtaeva et al. 2009). In addition, the presence of the $\beta$-subunit is required for the activity of the enzyme. Particularly, reduction of disulfide bridges in the $\beta$-subunit results in inactivation of the enzyme and loss of cation occlusion (Lutsenko and Kaplan 1993). Furthermore, different isoforms of the Na,K-ATPase $\beta$-subunit are known to perform "fine tuning" of the ion-transporting function (Crambert et al. 2000; Geering 2008; Stanley et al. 2015). Moreover, the Na,KATPase $\beta$-subunit participates in maintaining epithelial cell polarity and cell adhesion by direct binding of the extracellular domains of the $\beta$-subunits located in neighboring cells (Cereijido et al. 2012; Vagin et al. 2012). Both proteinaceous sequences and $\mathrm{N}$-glycans are involved in this $\beta: \beta$ interactions (Tokhtaeva et al. 2011). Disruption of the Na,K-ATPase$\beta: \beta$ interactions either by altering the $\mathrm{N}$-glycosylation site sequences or by adding competing Na,K-ATPase- $\beta$-specific antibodies prevents formation of junctional complexes that leads to an elevated paracellular permeability (Tokhtaeva et al. 2012; Vagin et al. 2008). Moreover, the Na,K-ATPase $\beta$-subunit is involved in the regulation of desmosomes and actin dynamics (Geering 2008; Rajasekaran et al. 2005, 2001b).

The activity and PM expression of the Na,K-ATPase $\alpha: \beta$-complex is modulated by a third regulatory $\gamma$-subunit, belonging to the FXYD protein family (Sweadner and Rael 2000). As reviewed previously, seven different FXYD proteins that share a PFxYD motif in their $\mathrm{N}$ terminus have been detected in mammalian cells (Clausen et al. 2017; Geering 2006). The expression and function of FXYD proteins are tissue-specific and most of them act as inhibitors of $\mathrm{Na}, \mathrm{K}-\mathrm{ATPa}$ e activity by either lowering the affinity of the transported ions to the enzyme or by modifying the pumping activity of the Na,K-ATPase (Garty and Karlish 2006;
Geering 2005). In addition, it has been demonstrated that FXYD5 impairs cellular adhesion by disruption of cellular junctions between $\mathrm{Na}, \mathrm{K}$-ATPase $\beta$-subunits in epithelial cells (Tokhtaeva et al. 2016) and increase the surface expression of the tumor necrosis factor (TNF)- $\alpha$ receptor; thus, playing a pro-inflammatory role (Lubarski-Gotliv et al. 2016).

Generally, short-term regulation of the Na,K-ATPase involves mechanisms that affect the PM abundance of the enzyme and/or the function of PM-localized Na,K-ATPase molecules. Various stimuli trigger signaling pathways that mediate retrieval of the assembled Na,K-ATPase from the cellular PM via endocytosis. These processes are well characterized in the alveolar epithelium in the context of hypoxia and hypercapnia and are mediated by second messengers and intracellular kinases. Both hypoxia and hypercapnia lead to a marked and transient elevation of intracellular $\mathrm{Ca}^{2+}$ concentrations that subsequently stimulates AMP-activated protein kinase (AMPK) (Gusarova et al. 2009, 2011; Vadasz et al. 2008). In the setting of hypercapnia, stimulation of AMPK also requires prior activation of extracellular signal-regulated kinase (ERK) $1 / 2$ (Welch et al. 2010). In turn, AMPK drives translocation of protein kinase $\mathrm{C}$ (PKC)- $\zeta$ to the PM, where the kinase directly phosphorylates the $\mathrm{Na}, \mathrm{K}$ ATPase $\alpha$-subunit at $\operatorname{Ser}^{18}$, thereby initiating internalization of the Na,K-ATPase from the cell surface (Gusarova et al. 2009, 2011; Vadasz et al. 2008). AMPK and PKC- $\zeta$ also activate the c-Jun N-terminal kinase (JNK) $1 / 2$ that subsequently promotes actin reorganization via phosphorylation of the LIM domain-only 7b (LMO7b) protein resulting in endocytosis of the Na,K-ATPase (Dada et al. 2015; Vadasz et al. 2012a). Of note, stimulation of AMPK and reduction of $\mathrm{Na}, \mathrm{K}$-ATPase activity have also been demonstrated in the settings of influenza virus infection (Peteranderl et al. 2016). Interestingly, cAMP has also been shown to be involved in the short-term regulation of the Na,K-ATPase PM expression via stimulation of protein kinase A (PKA) activity by soluble adenylyl cyclase (sAC) and modifications of the actin cytoskeleton (Lecuona et al. 2013). The involvement of cAMP (Bertorello et al. 1999), AMPK (Lang and Foller 2014), PKA (Cheng et al. 1997; Poulsen et al. 2010) and $\mathrm{Ca}^{2+}$ signaling (Aperia et al. 2016, 2020) has also been clearly demonstrated in additional studies focusing on the regulation of $\mathrm{Na}, \mathrm{K}$-ATPase abundance at the PM and/or on activity of the enzyme.

Long-term regulation of the $\mathrm{Na}, \mathrm{K}$-ATPase is primarily mediated at the transcriptional level by altering mRNA levels of its subunits. Previous reports have shown that hypoxia, glucocorticoids, insulin, progesterone, thyroid hormones, transforming growth factor- $\beta$ and fibroblast growth factors alter transcription of the Na,K-ATPase (Clerici and Matthay 2000; Devarajan and Benz 2000; Li and Langhans 2015). Interestingly, transcriptional regulation of the transporter 
often has a positive feedback loop, where upregulation of a single $\mathrm{Na}, \mathrm{K}$-ATPase subunit leads to stimulation of the transcription and translation of another one. For example, overexpression of the $\mathrm{Na}, \mathrm{K}$-ATPase $\beta$-subunit results in upregulation of the $\alpha$-subunit of the enzyme (Azzam et al. 2002; Rajasekaran et al. 2004).

The function of the Na,K-ATPase critically depends on its tissue expression and localization. In the lungs, the $\mathrm{Na}, \mathrm{K}-$ ATPase drives vectorial transport of $\mathrm{Na}^{+}$and in concerted action with epithelial sodium channels $(\mathrm{ENaC})$, thereby generating an osmotic gradient that drives passive movement of water through epithelial monolayers; thus, maintaining a minimal epithelial lining fluid volume (Vadasz et al. 2007). Apart from the lungs, various other tissues and organs utilize the $\mathrm{Na}, \mathrm{K}$-ATPase-driven $\mathrm{Na}^{+}$transport to maintain their functions. For example, the transporter participates in heart muscle metabolism (Shattock et al. 2015), drives vascular and endothelial functions, regulates reuptake of neurotransmitters in neurons (Mohan et al. 2019), controls electrolyte balance, blood $\mathrm{pH}$ and pressure and modulates reabsorption of amino acids and glucose in kidneys (Clausen et al. 2017; Matsuzaki et al. 2007). Due to its numerous functions and ubiquitous expression, dysfunction of the Na,K-ATPase has been linked to several pathological conditions and diseases. It is well documented that dysregulation of the Na,K-ATPase function leads among others to lung edema formation and persistence thus leading to progression of acute respiratory failure (Matthay et al. 2019; Mutlu and Sznajder 2005; Sznajder et al. 2002; Vadasz et al. 2007). In line with this notion, it has recently been demonstrated that knockout of the $\mathrm{Na}, \mathrm{K}$-ATPase $\beta$-subunit is associated with reduced alveolar fluid clearance in murine lungs in vivo (Flodby et al. 2016). Dysregulation of the Na,K-ATPase also leads to heart muscle hypertrophy and manifestation of chronic heart failure (Shattock et al. 2015), diabetes (Vague et al. 2004) and obesity (Obradovic et al. 2013). The dysfunction of the Na,KATPase during these conditions might be a consequence of expedited retrieval of the transporter from the PM or a reduced delivery of the enzyme to the cell surface. To what extent these mechanisms may involve altered protein folding and assembly of the Na,K-ATPase subunits in the ER is currently a topic of intense research in our laboratories.

\section{Protein Maturation, ER Stress and Unfolded Protein Response}

Approximately one-third of the cellular proteome, most of the secreted and all PM proteins, including the $\mathrm{Na}, \mathrm{K}-$ ATPase subunits, undergo co- and post-translational maturation in the ER (Brodsky and Skach 2011). The ER is a specific cellular organelle that coordinates co- and post-translational protein modifications, such as $\mathrm{N}$-linked glycosylation, reduction of disulfide bonds, cleavage of sequences, proline isomerization and addition of glycophosphatidylinositol-anchors (Ellgaard and Helenius 2003; Ellgaard et al. 2018). In order to perform these processes, the ER requires high $\mathrm{Ca}^{2+}$ levels, an oxidizing environment and high levels of ATP (Jager et al. 2012). Furthermore, proper protein folding is tightly coordinated by specific ER-resident chaperones, mostly by binding immunoglobulin protein (BiP, also known as GRP78), which can facilitate folding of all proteins and by calnexin or calreticulin that facilitate folding of glycoproteins. In addition, protein oxidation reactions are controlled by reductases, such as DnaJ homolog subfamily B member (ERdj3-6), protein disulfide-isomerase A3 (ERp57) or endoplasmic reticulum oxidoreductase-1 $\alpha$ (ERo1 $\alpha$ ) (Halperin et al. 2014). Addition of a 14-oligosaccharide core (Glc3Man9GlcNAc2) from a phosphate precursor or lipid carrier to the N-glycosylation site of the nascent folding peptide by glycosyltransferases results in formation of a monoglycosylated glycoprotein, thereby enhancing interaction of the folding protein with calnexin and calreticulin, thus activating the protein maturation cycle in the ER (Aebi 2013; Ellgaard and Helenius 2003).

The calnexin/calreticulin cycle is a central regulator of folding, quality control and degradation of newly-made glycoproteins (Wang and Kaufman 2016). Diverse physiological and pathological stimuli may affect protein structure, the folding environment of and the chaperone activity in the ER, thus inducing accumulation of misfolded or unfolded proteins in the ER and subsequent ER stress (Wang and Kaufman 2016). In particular, a decrease in calcium levels, changes in redox conditions or a reduction of ATP levels in the ER have been shown to impair ER homeostasis and induce ER stress (Han et al. 2013; Sano and Reed 2013). In response to ER stress, the unfolded protein response (UPR) is activated. Up to now, three main UPR pathways, termed by ER-localized receptors, namely inositol-requiring enzyme 1 (IRE1), protein kinase RNA-activated (PKR)-like ER kinase (PERK) and activating transcription factor-6 (ATF6) have been characterized. A dissociation of BiP from the ER-receptors, due to attachment of the chaperone to accumulated unfolded or misfolded proteins, leads to autophosphorylation and activation of the receptors. The UPR pathways initially aim to restore ER homeostasis by decreasing protein synthesis, by enhancing chaperone activity and by activating ER-associated degradation (ERAD) of the unfolded or misfolded proteins. However, if the UPR fails to restore ER homeostasis, a maladaptive response is activated that results in cellular death via apoptotic pathways (Almanza et al. 2019; Hwang and Qi 2018). 


\section{Maturation of the Na,K-ATPase in the ER}

The ER plays a crucial role in the folding of the Na,KATPase prior to delivery of the enzyme to the PM. Our current understanding on the maturation processes of the transporter in the ER is depicted in Fig. 1. Both co- and post-translational folding of the Na,K-ATPase subunits are coordinated by ER-resident chaperons, such as $\mathrm{BiP}$ and calnexin (Beggah et al. 1996; Beggah and Geering 1997; Tokhtaeva et al. 2010b). Previous reports suggest that both the unassembled $\mathrm{Na}, \mathrm{K}$-ATPase $\alpha$ - and $\beta$-subunits interact with BiP (Beggah et al. 1996). Furthermore, it has been shown that BiP plays a major role in the maturation of the $\mathrm{Na}, \mathrm{K}$ ATPase $\beta$-subunit. Folded Na,K-ATPase $\beta_{1}$ - or $\beta_{2}$-subunits have several maturation states in the ER and either bind to $\alpha$-subunits of the Na,K-ATPase and are subsequently guided for further maturation in the Golgi or bind to $\mathrm{BiP}$ and are subsequently retained in the ER and degraded by the ERAD machinery (Tokhtaeva et al. 2010b). In addition, inhibition of glycan-calnexin interactions or deletion of N-glycosylation sites of the Na,K-ATPase- $\beta_{1}$ increases ER retention of the enzyme and its binding to BiP but does not affect assembly with Na,K-ATPase- $\alpha_{1}$ (Tokhtaeva et al. 2010b). In contrast, $\mathrm{Na}, \mathrm{K}$-ATPase- $\beta_{2}$ is co-translationally bound to calnexin and disruption of this binding or decrease in N-glycosylation prevents the $\alpha: \beta$-complex formation. Moreover, deletions or mutations in the Na,K-ATPase $\alpha_{1}: \beta_{1}$ or $\alpha_{1}: \beta_{2}$ interacting regions impair $\mathrm{Na}, \mathrm{K}$-ATPase $\alpha: \beta$-complex formation, increase interaction of unassembled $\mathrm{Na}, \mathrm{K}-\mathrm{ATPase}$ subunits with BiP, ER retention and subsequent degradation (Tokhtaeva et al. 2009, 2010b). Interestingly, the degree of ER retention of the Na,K-ATPase subunits appears to be cell specific and is presumably dependent on different ratios of newly synthetized $\alpha$ - and $\beta$-subunits in different cell types (Marcus et al. 2020).

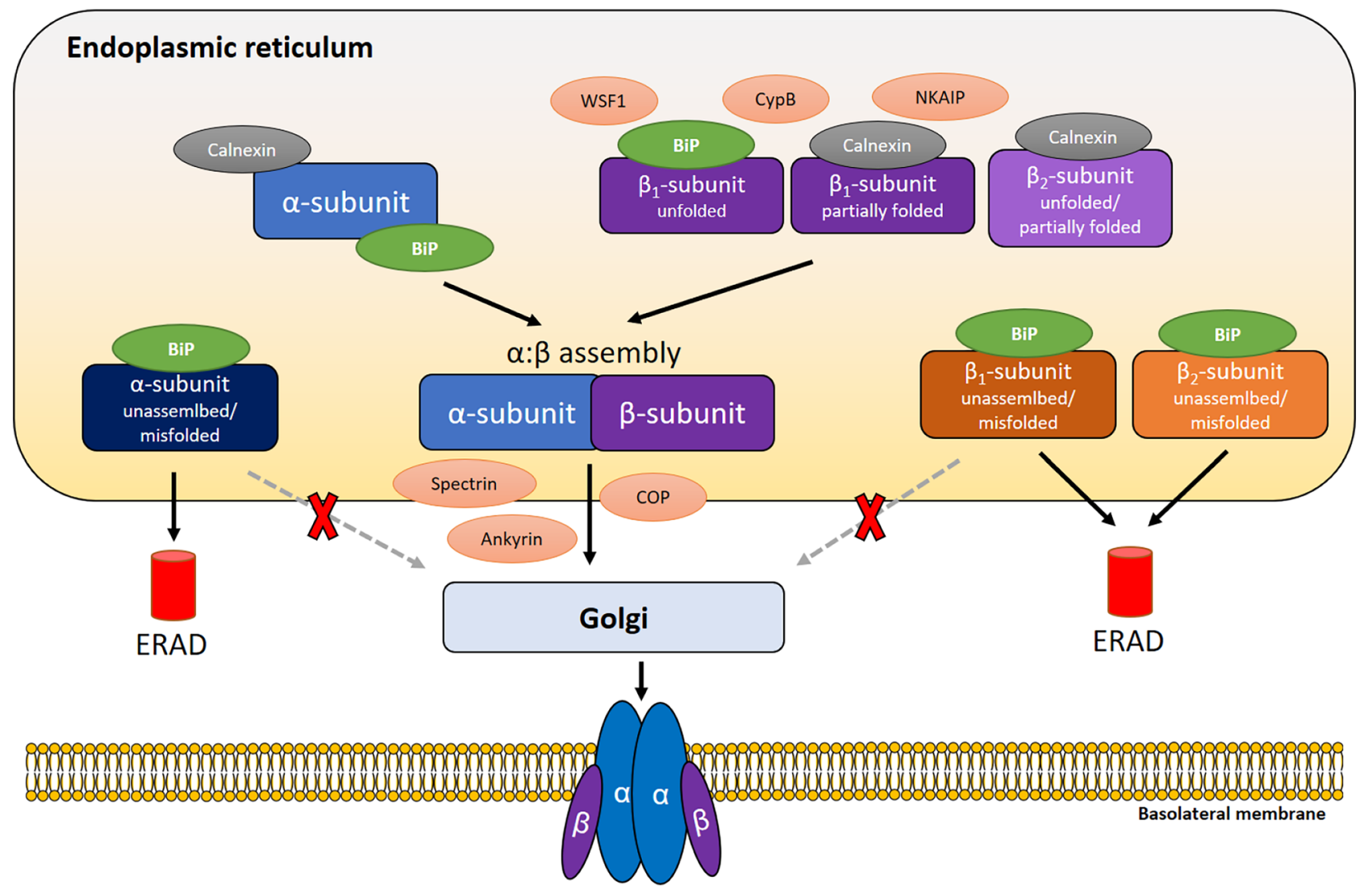

Fig. 1 Schematic representation of Na,K-ATPase folding in the endoplasmic reticulum. The Na,K-ATPase $\alpha$ - and $\beta$-subunits are present in the ER in different physiological or pathophysiological states, including properly folded, unfolded or misfolded subunits of the enzyme and assembled complexes. Calnexin and BiP are ER chaperones that assist the folding of the Na,K-ATPase subunits with isoform specificity and preferential binding properties. Additionally, wolframin (WSF1), cyclophilin B (CypB) and Na,K-ATPase interacting protein
(NKAIP) associate with the subunits of the Na,K-ATPase in the ER with divers functions. Only assembled $\mathrm{Na}, \mathrm{K}$-ATPase $\alpha$ : $\beta$-complexes can exit the ER and transferred to Golgi, whereas unassembled or misfolded subunits are retained with the assistance of $\mathrm{BiP}$ and targeted for endoplasmic reticulum-associated degradation (ERAD). Spectrin, ankyrin and coated proteins (COP) assist trafficking of assembled Na,K-ATPase $\alpha: \beta$-complexes from the ER to the Golgi apparatus 
Most importantly, it has been demonstrated that the individual unassembled subunits of the Na,K-ATPase cannot leave the ER (Tokhtaeva et al. 2009). The abovedescribed chaperone-assisted processes in the maturation of the $\mathrm{Na}, \mathrm{K}$-ATPase ensure that only intact $\mathrm{Na}, \mathrm{K}-\mathrm{ATPase}-\alpha: \beta$ heterodimers with a proper stoichiometric ratio of $1: 1$ can be exported to the Golgi for subsequent maturation (Tokhtaeva et al. 2009). During trafficking from the ER to the Golgi, the Na,K-ATPase interacts with coat proteins (COP), which form specific vesicles required for retrograde transport from the Golgi to the ER or anterograde movement through the Golgi cisternae. Previous studies have reported that although $\mathrm{Na}, \mathrm{K}$-ATPase $\alpha$-subunit may directly interact with COP, only $\alpha$-subunits assembled with the $\beta$-subunits are able to translocate into the Golgi compartments. The unassembled $\alpha$-subunits are retained in the ER and degraded via a proteasome-dependent mechanism (Morton et al. 2010). This finding underlines the importance of the Na,K-ATPase $\alpha$ : $\beta$-complex formation in the trafficking of the transporter to the PM.

Glycosylation also plays an important role in the maturation and trafficking of the Na,K-ATPase. All three isoforms of the $\beta$-subunit are $\mathrm{N}$-glycosylated, whereas some FXYD proteins are O-glycosylated. During the initial step of $\mathrm{Na}, \mathrm{K}$ ATPase- $\beta$ glycosylation in the ER, and oligosaccharide core is added, which results in a shift of the molecular weight of the protein by formation of high mannose type of N-glycans (Tokhtaeva et al. 2010b). During subsequent maturation of the Na,K-ATPase in the ER, N-glycans are added to the $\beta$-subunit by assistance of ER- and Golgi-resident glycosidases and glycosyltransferases. This leads to the formation of hybrid- or complex-type N-glycans (Vagin et al. 2012). Of note, $\mathrm{N}$-glycans are not essential for $\mathrm{Na}, \mathrm{K}$-ATPase $\alpha_{1}: \beta_{1}$ assembly, insertion of the enzyme to the PM or its activity (Vagin et al. 2012). In contrast, N-glycans are critical for the formation, maintenance and regulation of epithelial junctions (Vagin et al. 2006, 2008). On the other hand, removal of the N-glycosylation sites is associated with increased susceptibility to degradation of the Na,K-ATPase $\beta$-subunit in the ER (Laughery et al. 2003). In contrast to the $\beta_{1}$ subunit, the presence of $\mathrm{N}$-glycans plays an important role in the assembly of the $\alpha$-subunit with the $\beta_{2}$-subunit of the Na,K-ATPase (Tokhtaeva et al. 2010a). Moreover, disulfide bonds in the Na,K-ATPase $\beta$-subunit are not necessary for the assembly of the heterodimer, however, are crucial for ER exit and PM targeting of the transporter, since truncated versions or mutants of the Na,K-ATPase- $\beta$ with disulfide bridge disruptions are able to assemble with the $\alpha$-subunit but are retained in the ER (Laughery et al. 2003).

Apart from ER-resident chaperones, other proteins may participate in the maturation of the Na,K-ATPase. For example, the Na,K-ATPase- $\beta_{1}$ has been shown to interact with wolframin (WSF1), an ER-localized protein, as initially identified in a yeast two-hybrid screening assay. Of note, WSF1 mutants or a knockdown of WSF1 reduce the expression of both Na,K-ATPase- $\beta_{1}$ - and $-\alpha_{1}$ at the PM, suggesting that WSF1 may be required for maturation of the $\mathrm{Na}$,K-ATPase in the ER (Zatyka et al. 2008). Another report showed an interaction between the $\mathrm{Na}, \mathrm{K}$-ATPase $\beta_{1}$-subunit and cyclophilin $\mathrm{B}(\mathrm{CypB})$. CypB is an enzyme from the cyclophilin family, members of which are known to have peptidyl prolyl cis-trans isomerase activity, thus possessing chaperon activity and are involved in the folding and repair of proteins. CypB expresses an ER-directed signal sequence and participates in protein maturation in the ER. Interestingly, silencing $\mathrm{CypB}$ results in an increase of ER abundance of Na,K-ATPase- $\alpha$ and $-\beta$ as well as decreased transporter activity (Sune et al. 2010). Although these results suggest that CypB might regulate maturation of the Na,K-ATPase in the ER, the exact molecular mechanisms remain to be determined. Another protein that has been found to interact with the Na,K-ATPase $\beta$-subunit in the ER and in lysosomes is Na,K-ATPase interacting protein (NKIP), an endogenous suppressor of the activity of the enzyme with a currently unknown role in ER processing of the Na,K-ATPase (Pratscher et al. 2008). Furthermore, it has been shown that the Golgi-localized spectrin-ankyrin skeleton is also required for $\mathrm{Na}, \mathrm{K}-\mathrm{ATPase}$ trafficking from the ER to the Golgi. Interestingly, genetic modification of spectrin blocks transport of both Na,K-ATPase- $\alpha$ and $-\beta$ from the ER, but does not interfere with the formation of Golgi stacks, the distribution of COP or trafficking and surface expression of E-cadherin, suggesting selectivity for the Na,K-ATPase (Devarajan et al. 1997). In line with this notion, blocking the ankyrin-binding sequence of the Na,K-ATPase- $\alpha_{1}$ inhibits the ER to Golgi transport of the subunit (Stabach et al. 2008). Interestingly, ankyrin and $\mathrm{Na}, \mathrm{K}-\mathrm{ATP}$ ase have been found to interact with the ER-localized inositol trisphosphate receptor (InsP3R), thus directly participating in the regulation of luminal $\mathrm{Ca}^{2+}$ concentration of the ER (Cook et al. 2012; Turner et al. 2016). Whether there is a feedback loop among maturation of the Na,K-ATPase in the ER, trafficking of the enzyme from the ER to the Golgi and ER $\mathrm{Ca}^{2+}$ concentrations, is currently unknown and warrants further investigation.

\section{ER Dysfunction-Related Impaired Maturation of the $\mathrm{Na}, \mathrm{K}-\mathrm{ATPa}$ e in Disease States}

Recent studies reported that changes in the ER microenvironment, such as a decrease in $\mathrm{Ca}^{2+}$ levels, ATP or alterations in the oxidative environment of the ER, lead to protein misfolding or unfolding, induce ER stress and activate UPR pathways (Araki and Nagata 2011; Wang and Kaufman 2016). Decreased PM expression and function of 
the $\mathrm{Na}, \mathrm{K}$-ATPase have been shown in various pathological lung, heart, renal and neurological conditions and diseases (Bonilla et al. 1991; de Lores Arnaiz and Ordieres 2014; Fekete et al. 2008; Matsuzaki et al. 2007; Shattock et al. 2015; Vadasz et al. 2007).

It has been reported that cadmium $\left(\mathrm{Cd}^{2+}\right)$, which promotes oxidative stress and lipid peroxidation, induces ER retention of the $\mathrm{Na}, \mathrm{K}$-ATPase $\beta_{1}$ and $\beta_{2}$ subunits. After $\mathrm{Cd}^{2+}$ treatment, both subunits are retained in ER in a dosedependent manner, whereas retention of the $\beta_{2}$-subunit appears to be more prominent. Additionally, $\mathrm{Cd}^{2+}$ treatment results in a marked and selective increase in BiP levels as opposed to calnexin, which in turn rescues maturation of the $\mathrm{Na}, \mathrm{K}$-ATPase $\beta_{1}$ - but not of the $\beta_{2}$-subunit. As the Na,K-ATPase $\alpha_{1}: \beta_{1}$-complex plays a pivotal role in maintaining cellular membrane potential and thus in cellular survival, the resistance of the $\mathrm{Na}, \mathrm{K}-\mathrm{ATPa} e-\beta_{1}$ to ER stress may serve as an adaptive mechanism during dysfunction of the ER potentially contributing to cellular resilience (Tokhtaeva et al. 2010b).

Various acute and chronic lung diseases are associated with an elevation in carbon dioxide $\left(\mathrm{CO}_{2}\right)$ levels in blood and tissues, a condition termed hypercapnia (Vadasz et al. 2012b). It has been previously shown that an acute exposure of lung alveolar epithelial cells to elevated $\mathrm{CO}_{2}$ concentrations results in downregulation of Na,K-ATPase function by increased trafficking of the enzyme from the PM into intracellular compartments (Dada et al. 2015; Lecuona et al. 2013; Vadasz et al. 2008; Welch et al. 2010). Additionally, it has recently been shown that sustained hypercapnia impairs maturation of the transporter in the ER. In particular, elevated $\mathrm{CO}_{2}$ levels promote ER retention of the Na,K-ATPase $\beta$-subunit in lung epithelial cells, thus decreasing PM abundance and activity of the enzyme (Kryvenko et al. 2020). These negative effects of $\mathrm{CO}_{2}$ on the $\mathrm{Na}, \mathrm{K}$-ATPase are driven by alterations of the oxidizing environment and direct carbonylation of the Na,K-ATPase $\beta$-subunit in the ER during hypercapnia, which impairs $\alpha: \beta$-complex formation and subsequent trafficking to the $\mathrm{PM}$. Interestingly, both $\mathrm{BiP}$ and calnexin interact with $\mathrm{Na}$,K-ATPase- $\beta_{1}$ upon $\mathrm{CO}_{2}$ exposure; however, levels of $\mathrm{BiP}$ remain unchanged, suggesting that as opposed to $\mathrm{Cd}^{2+}$ treatment, upon hypercapnia folding of Na,K-ATPase- $\beta_{1}$ is not rescued (Kryvenko et al. 2020). Another recent study suggests that a decrease of the expression of the $\mathrm{Na}, \mathrm{K}$-ATPase $\beta_{1}$-subunit drives ER stress and promotes a fibrotic phenotype in alveolar epithelial cells. Interestingly, specific knockdown of $\mathrm{Na}, \mathrm{K}-\mathrm{ATPase}-\beta_{1}$ leads to increased expression of $\mathrm{BiP}$, fibronectin and $\alpha$-smooth muscle actin, thus activating ER stress and fibrotic signaling pathways, suggesting that mechanisms that impair expression of the $\mathrm{Na}$,K-ATPase $\beta_{1}$-subunit may contribute to development of lung fibrosis (Li et al. 2019).
Another recent report shows that infection of gastric epithelial cells with Helicobacter pylori impairs chaperoneassisted maturation of newly synthetized Na,K-ATPase molecules prior to trafficking of the enzyme to the PM (Marcus et al. 2020). An infection with $H$. pylori prevents association of BiP with both the $\alpha$ - and the $\beta$-subunits of the $\mathrm{Na}, \mathrm{K}-$ ATPase in the ER, thus, causing defective folding and subsequent ubiquitination and proteasomal degradation of the $\mathrm{Na}$,K-ATPase subunits, thereby inhibiting formation of $\alpha_{1}: \beta_{1}$ heterodimers. Interestingly, this impairment of Na,K-ATPase maturation in the ER is not associated with ER stress, increased total levels of $\mathrm{BiP}$ or prevention of BiP-assisted chaperone folding of other proteins. However, overexpression of BiP, inhibition of protein synthesis or blocking of proteasomal degradation partially rescue maturation of the $\mathrm{Na}, \mathrm{K}-\mathrm{ATPase}$ upon $H$. pylori infection. A decrease in $\mathrm{Na}, \mathrm{K}-$ ATPase levels has been observed in chronically infected children and in gastric epithelia of gerbils in vivo (Marcus et al. 2020). Although a direct link between the decreased levels of the Na,K-ATPase and the impairment of the barrier function of gastric epithelia by $H$. pylori is to be explored, the expected physiologic consequence is a decrease in the inward $\mathrm{Na}^{+}$gradient with intracellular accumulation of $\mathrm{Na}^{+}$, resulting in the impairment of ion homeostasis and nutrient uptake, cell swelling, damage to cell junctions and subsequent gastric injury. Along with these expectations, imaging studies demonstrated accumulation of $H$. pylori clusters at the junctions between significantly swollen cells in the infected epithelium from human biopsy samples (Fiocca et al. 1987). Further understanding of $H$. pylori-induced $\mathrm{Na}, \mathrm{K}-\mathrm{ATPase}$ degradation will provide insights for protection against advanced disease and may provide novel therapeutic targets in the context of gastric epithelial injury.

Mutations in the catalytic $\alpha$-subunit of the Na,K-ATPase have been shown to be involved in the pathogenesis of the several neurological disorders, such as epilepsy, cerebellar ataxia, familial hemiplegic migraine and axonal Charcot-Marie-Tooth neuropathy (Dard et al. 2015; Friedrich et al. 2016; Lassuthova et al. 2018). However, the clinical manifestations of some of these disorders are not a consequence of impaired PM function of the Na,K-ATPase but rather the altered trafficking of the transporter (Arystarkhova et al. 2019). For example, a recent report demonstrates that mutations of the Na,K-ATPase $\alpha_{3}$-isoform, which have been found in severe cases of early infantile epileptic encephalopathy, result in decreased biosynthesis and trafficking of the transporter, but do not alter activity of the enzyme. Instead, these mutations induced ER retention of the $\beta_{1}$-subunit and subsequent activation of UPR via increased phosphorylation of eukaryotic initiation factor $2 \alpha$ and leading to ERAD of the $\alpha_{3}$-subunit. In line with this notion, treatment with the chemical chaperone 4-PBA appears to attenuate the effects of the Na,K-ATPase $\alpha_{3}$ mutations, rescuing the ER-retained 
$\beta_{1}$-subunit and improving cellular morphology (Arystarkhova et al. 2020).

It has previously been shown that in kidney biopsies from patients with autosomal dominant polycystic kidney disease, the Na,K-ATPase $\beta_{1}$-subunit is predominantly expressed in the cytoplasm and the ER, as opposed to kidney biopsies from patients without the disease in which the $\alpha_{1^{-}}$and $\beta_{1^{-}}$ subunits of the transporter are localized at the basolateral membrane of renal tubules. Interestingly, ER retention of the $\beta_{1}$-subunit is associated with a compensatory increase of the $\beta_{2}$-subunit and apical, but not basolateral, expression of the Na,K-ATPase $\alpha_{1}: \beta_{2}$-complex (Wilson et al. 2000). In contrast, this mislocation was not observed in animal models of autosomal dominant polycystic kidney disease (Kawa et al. 1994; Takahashi et al. 1997; Thomson et al. 2003). Thus, mistargeting of the Na,K-ATPase in the setting of this disease remains controversial (Zatti et al. 2005). Interestingly, a recent study observes aberrant apical expression of the Na,K-ATPase upon influenza A virus infection of lung epithelial cells both in vitro and in vivo (Peteranderl et al. 2019). However, the exact mechanism of this phenomenon remains unknown. Of note, various studies also suggest an aberrant localization of the Na,K-ATPase secondary to an infection with severe acute respiratory syndrome coronavirus 2 (SARS-CoV-2), which may contribute to alveolar epithelial barrier dysfunction, persistence of pulmonary edema and deterioration of patients with coronavirus disease 2019 (COVID-19)-associated acute respiratory distress syndrome (Kryvenko and Vadasz 2021).

In conclusion, recent evidence suggests that the ER plays an essential role in co- and post-translational processing of $\mathrm{Na}, \mathrm{K}-\mathrm{ATPase}$ subunits and assembly of the $\alpha: \beta$ heterodimer complexes. The maturation of the Na,K-ATPase is a multifaceted, subunit-specific process that is negatively affected by alterations in ER homeostasis, causing misfolding of the proteins, exacerbating ER stress and may lead to UPR. As impaired maturation of the Na,K-ATPase is associated with various disease states, better understanding of these mechanisms may lead to novel therapeutic means.

Author Contributions VK and IV drafted the manuscript. VK, OV, LAD, JIS and IV edited and approved final version of the manuscript.

Funding Open Access funding enabled and organized by Projekt DEAL. This work was supported by grants from the Federal Ministry of Education and Research (German Center for Lung Research [DZL/ALI 1.5 and 3.4]), the Hessen State Ministry of Higher Education, Research and the Arts (Landes-Offensive zur Entwicklung Wissenschaftlich-ökonomischer Exzellenz [LOEWE]), the von Behring Röntgen Foundation (Project 66-LV07) and the German Research Foundation (DFG/KFO309, P5; The Cardio-Pulmonary Institute (EXC 2026; Project ID: 390649896) (to I.V.) and an MD/PhD start-up grant (DFG/KFO309, MD/PhD) (to V.K.) as well as the National Institutes of Health (HL-147070) (to J.I.S.), AG-049665 and HL-154686 (both to J.I.S and L.A.D.).

\section{Declarations}

Conflict of interest The authors have no conflicts of interest to declare that are relevant to the content of this article.

Open Access This article is licensed under a Creative Commons Attribution 4.0 International License, which permits use, sharing, adaptation, distribution and reproduction in any medium or format, as long as you give appropriate credit to the original author(s) and the source, provide a link to the Creative Commons licence, and indicate if changes were made. The images or other third party material in this article are included in the article's Creative Commons licence, unless indicated otherwise in a credit line to the material. If material is not included in the article's Creative Commons licence and your intended use is not permitted by statutory regulation or exceeds the permitted use, you will need to obtain permission directly from the copyright holder. To view a copy of this licence, visit http://creativecommons.org/licenses/by/4.0/.

\section{References}

Aebi M (2013) N-linked protein glycosylation in the ER. Biochim Biophys Acta 1833:2430-2437. https://doi.org/10.1016/j.bbamcr. 2013.04.001

Almanza A et al (2019) Endoplasmic reticulum stress signalling-from basic mechanisms to clinical applications. FEBS J 286:241-278. https://doi.org/10.1111/febs. 14608

Aperia A (2007) New roles for an old enzyme: Na, K-ATPase emerges as an interesting drug target. J Intern Med 261:44-52. https://doi. org/10.1111/j.1365-2796.2006.01745.x

Aperia A, Akkuratov EE, Fontana JM, Brismar H (2016) Na+-K+ATPase, a new class of plasma membrane receptors. Am J Physiol Cell Physiol 310(7):C491-C495. https://doi.org/10.1152/ ajpcell.00359.2015

Aperia A, Brismar H, Uhlen P (2020) Mending fences: Na,K-ATPase signaling via $\mathrm{Ca}(2+)$ in the maintenance of epithelium integrity. Cell Calcium 88:102210. https://doi.org/10.1016/j.ceca.2020. 102210

Araki K, Nagata K (2011) Protein folding and quality control in the ER. Cold Spring Harb Perspect Biol. https://doi.org/10.1101/cshpe rspect.a007526

Arystarkhova E et al (2019) Factors in the disease severity of ATP1A3 mutations: impairment, misfolding, and allele competition. Neurobiol Dis 132:104577. https://doi.org/10.1016/j.nbd.2019. 104577

Arystarkhova E, Ozelius LJ, Brashear A, Sweadner KJ (2020) Misfolding, altered membrane distributions, and the unfolded protein response contribute to pathogenicity differences in Na,K-ATPase ATP1A3 mutations. J Biol Chem. https://doi.org/10.1074/jbc. RA120.015271

Azzam ZS, Dumasius V, Saldias FJ, Adir Y, Sznajder JI, Factor P (2002) Na,K-ATPase overexpression improves alveolar fluid clearance in a rat model of elevated left atrial pressure. Circulation 105:497-501. https://doi.org/10.1161/hc0402.102848

Beggah AT, Geering K (1997) Alpha and beta subunits of Na,K-ATPase interact with BiP and calnexin. Ann N Y Acad Sci 834:537-539. https://doi.org/10.1111/j.1749-6632.1997.tb52311.x

Beggah A, Mathews P, Beguin P, Geering K (1996) Degradation and endoplasmic reticulum retention of unassembled alpha- and 
beta-subunits of $\mathrm{Na}, \mathrm{K}-\mathrm{ATPase}$ correlate with interaction of BiP. J Biol Chem 271:20895-20902. https://doi.org/10.1074/jbc.271. 34.20895

Bertorello AM, Ridge KM, Chibalin AV, Katz AI, Sznajder JI (1999) Isoproterenol increases $\mathrm{Na}+\mathrm{K}+$-ATPase activity by membrane insertion of alpha-subunits in lung alveolar cells. Am J Physiol 276:L20-L27. https://doi.org/10.1152/ajplung.1999.276.1.L20

Bonilla S, Goecke IA, Bozzo S, Alvo M, Michea L, Marusic ET (1991) Effect of chronic renal failure on Na,K-ATPase alpha 1 and alpha 2 mRNA transcription in rat skeletal muscle. J Clin Invest 88:2137-2141. https://doi.org/10.1172/JCI115544

Brodsky JL, Skach WR (2011) Protein folding and quality control in the endoplasmic reticulum: recent lessons from yeast and mammalian cell systems. Curr Opin Cell Biol 23:464-475. https://doi. org/10.1016/j.ceb.2011.05.004

Cereijido M, Contreras RG, Shoshani L, Larre I (2012) The Na+$\mathrm{K}+$-ATPase as self-adhesion molecule and hormone receptor. Am J Physiol Cell Physiol 302:C473-C481. https://doi.org/10. 1152/ajpcell.00083.2011

Cheng XJ, Hoog JO, Nairn AC, Greengard P, Aperia A (1997) Regulation of rat $\mathrm{Na}(+)-\mathrm{K}(+)$-ATPase activity by PKC is modulated by state of phosphorylation of Ser-943 by PKA. Am J Physiol 273:C1981-C1986. https://doi.org/10.1152/ajpcell.1997.273.6. C1981

Clausen MV, Hilbers F, Poulsen H (2017) The structure and function of the $\mathrm{Na}, \mathrm{K}$-ATPase isoforms in health and disease. Front Physiol 8:371. https://doi.org/10.3389/fphys.2017.00371

Clerici C, Matthay MA (2000) Hypoxia regulates gene expression of alveolar epithelial transport proteins. J Appl Physiol 88:18901896. https://doi.org/10.1152/jappl.2000.88.5.1890

Cook ZC, Gray MA, Cann MJ (2012) Elevated carbon dioxide blunts mammalian cAMP signaling dependent on inositol 1,4,5-triphosphate receptor-mediated $\mathrm{Ca} 2+$ release. J Biol Chem 287:26291-26301. https://doi.org/10.1074/jbc.M112. 349191

Crambert G et al (2000) Transport and pharmacological properties of nine different human Na,K-ATPase isozymes. J Biol Chem 275:1976-1986. https://doi.org/10.1074/jbc.275.3.1976

Dada LA et al (2015) High CO2 leads to Na,K-ATPase endocytosis via c-Jun amino-terminal kinase-induced LMO7b phosphorylation. Mol Cell Biol 35:3962-3973. https://doi.org/10.1128/MCB. 00813-15

Dard R, Mignot C, Durr A, Lesca G, Sanlaville D, Roze E, Mochel F (2015) Relapsing encephalopathy with cerebellar ataxia related to an ATP1A3 mutation. Dev Med Child Neurol 57:1183-1186. https://doi.org/10.1111/dmcn.12927

de Lores Arnaiz GR, Ordieres MG (2014) Brain Na(+), K(+)-ATPase activity in aging and disease. Int J Biomed Sci 10:85-102

Devarajan P, Benz EJ Jr (2000) Translational regulation of Na-KATPase subunit mRNAs by glucocorticoids. Am J Physiol Renal Physiol 279:F1132-1138. https://doi.org/10.1152/ajprenal.2000. 279.6.F1132

Devarajan P, Stabach PR, De Matteis MA, Morrow JS (1997) Na,KATPase transport from endoplasmic reticulum to Golgi requires the Golgi spectrin-ankyrin G119 skeleton in Madin Darby canine kidney cells. Proc Natl Acad Sci USA 94:10711-10716. https:// doi.org/10.1073/pnas.94.20.10711

Ellgaard L, Helenius A (2003) Quality control in the endoplasmic reticulum. Nat Rev Mol Cell Biol 4:181-191. https://doi.org/10. 1038/nrm 1052

Ellgaard L, Sevier CS, Bulleid NJ (2018) How are proteins reduced in the endoplasmic reticulum? Trends Biochem Sci 43:32-43. https://doi.org/10.1016/j.tibs.2017.10.006

Fekete A et al (2008) $\mathrm{Na}+, \mathrm{K}+$-ATPase is modulated by angiotensin II in diabetic rat kidney-another reason for diabetic nephropathy?
J Physiol 586:5337-5348. https://doi.org/10.1113/jphysiol.2008. 156703

Feschenko MS, Sweadner KJ (1995) Structural basis for speciesspecific differences in the phosphorylation of Na,K-ATPase by protein kinase C. J Biol Chem 270:14072-14077. https://doi.org/ 10.1074/jbc.270.23.14072

Figtree GA, Keyvan Karimi G, Liu CC, Rasmussen HH (2012) Oxidative regulation of the $\mathrm{Na}(+)-\mathrm{K}(+)$ pump in the cardiovascular system. Free Radic Biol Med 53:2263-2268. https://doi.org/10. 1016/j.freeradbiomed.2012.10.539

Fiocca R, Villani L, Turpini F, Turpini R, Solcia E (1987) High incidence of campylobacter-like organisms in endoscopic biopsies from patients with gastritis, with or without peptic ulcer. Digestion 38:234-244. https://doi.org/10.1159/000199597

Flodby P et al (2016) Knockout mice reveal a major role for alveolar epithelial type I cells in alveolar fluid clearance. Am J Respir Cell Mol Biol 55:395-406. https://doi.org/10.1165/rcmb. 2016-0005OC

Friedrich T, Tavraz NN, Junghans C (2016) ATP1A2 mutations in migraine: seeing through the facets of an ion pump onto the neurobiology of disease. Front Physiol 7:239. https://doi.org/ 10.3389/fphys.2016.00239

Garty H, Karlish SJ (2006) Role of FXYD proteins in ion transport. Annu Rev Physiol 68:431-459. https://doi.org/10.1146/annur ev.physiol.68.040104.131852

Geering K (2005) Function of FXYD proteins, regulators of $\mathrm{Na}, \mathrm{K}$ ATPase. J Bioenerg Biomembr 37:387-392. https://doi.org/10. 1007/s10863-005-9476-x

Geering K (2006) FXYD proteins: new regulators of Na-K-ATPase. Am J Physiol Renal Physiol 290:F241-250. https://doi.org/10. 1152/ajprenal.00126.2005

Geering K (2008) Functional roles of Na,K-ATPase subunits. Curr Opin Nephrol Hypertens 17:526-532. https://doi.org/10.1097/ MNH.0b013e3283036cbf

Gusarova GA et al (2011) Hypoxia leads to Na,K-ATPase downregulation via $\mathrm{Ca}(2+)$ release-activated $\mathrm{Ca}(2+)$ channels and AMPK activation. Mol Cell Biol 31:3546-3556. https://doi. org/10.1128/MCB.05114-11

Gusarova GA, Dada LA, Kelly AM, Brodie C, Witters LA, Chandel NS, Sznajder JI (2009) Alpha1-AMP-activated protein kinase regulates hypoxia-induced $\mathrm{Na}, \mathrm{K}$-ATPase endocytosis via direct phosphorylation of protein kinase $\mathrm{C}$ zeta. Mol Cell Biol 29:3455-3464. https://doi.org/10.1128/MCB.00054-09

Halperin L, Jung J, Michalak M (2014) The many functions of the endoplasmic reticulum chaperones and folding enzymes. IUBMB Life 66:318-326. https://doi.org/10.1002/iub.1272

Han J et al (2013) ER-stress-induced transcriptional regulation increases protein synthesis leading to cell death. Nat Cell Biol 15:481-490. https://doi.org/10.1038/ncb2738

Huang WH, Wang Y, Askari A, Zolotarjova N, Ganjeizadeh M (1994) Different sensitivities of the $\mathrm{Na}+/ \mathrm{K}(+)$-ATPase isoforms to oxidants. Biochim Biophys Acta 1190:108-114. https://doi.org/10.1016/0005-2736(94)90039-6

Hwang J, Qi L (2018) Quality control in the endoplasmic reticulum: crosstalk between ERAD and UPR pathways. Trends Biochem Sci 43:593-605. https://doi.org/10.1016/j.tibs.2018.06.005

Jager R, Bertrand MJ, Gorman AM, Vandenabeele P, Samali A (2012) The unfolded protein response at the crossroads of cellular life and death during endoplasmic reticulum stress. Biol Cell 104:259-270. https://doi.org/10.1111/boc.201100055

Jorgensen PL, Hakansson KO, Karlish SJ (2003) Structure and mechanism of Na,K-ATPase: functional sites and their interactions. Annu Rev Physiol 65:817-849. https://doi.org/10.1146/annur ev.physiol.65.092101.142558

Kanai R, Ogawa H, Vilsen B, Cornelius F, Toyoshima C (2013) Crystal structure of a $\mathrm{Na}+$-bound $\mathrm{Na}+\mathrm{K}+$-ATPase preceding 
the E1P state. Nature 502:201-206. https://doi.org/10.1038/ nature 12578

Kaplan JH (2002) Biochemistry of Na,K-ATPase. Annu Rev Biochem 71:511-535. https://doi.org/10.1146/annurev.biochem. 71.102201 .141218

Kawa G, Nagao S, Yamamoto A, Omori K, Komatz Y, Takahashi H, Tashiro Y (1994) Sodium pump distribution is not reversed in the DBA/2FG-pcy, polycystic kidney disease model mouse. J Am Soc Nephrol 4:2040-2049

Kryvenko V, Vadasz I (2021) Molecular mechanisms of Na,KATPase dysregulation driving alveolar epithelial barrier failure in severe COVID-19. Am J Physiol Lung Cell Mol Physiol. https://doi.org/10.1152/ajplung.00056.2021

Kryvenko V et al (2020) Hypercapnia impairs Na,K-ATPase function by inducing endoplasmic reticulum retention of the betasubunit of the enzyme in alveolar epithelial cells. Int J Mol Sci. https://doi.org/10.3390/ijms21041467

Lang F, Foller M (2014) Regulation of ion channels and transporters by AMP-activated kinase (AMPK). Channels (Austin) 8:20-28. https://doi.org/10.4161/chan.27423

Lassuthova P et al (2018) Mutations in ATP1A1 cause dominant charcot-marie-tooth type 2. Am J Hum Genet 102:505-514. https:// doi.org/10.1016/j.ajhg.2018.01.023

Laughery MD, Todd ML, Kaplan JH (2003) Mutational analysis of alpha-beta subunit interactions in the delivery of Na,K-ATPase heterodimers to the plasma membrane. J Biol Chem 278:3479434803. https://doi.org/10.1074/jbc.M302899200

Lecuona E, Sun H, Chen J, Trejo HE, Baker MA, Sznajder JI (2013) Protein kinase A-Ialpha regulates Na,K-ATPase endocytosis in alveolar epithelial cells exposed to high $\mathrm{CO}(2)$ concentrations. Am J Respir Cell Mol Biol 48:626-634. https://doi.org/10.1165/ rcmb.2012-03730C

Li Z, Langhans SA (2015) Transcriptional regulators of Na,K-ATPase subunits. Front Cell Dev Biol 3:66. https://doi.org/10.3389/fcell. 2015.00066

Li B, Huang X, Xu X, Ning W, Dai H, Wang C (2019) The profibrotic effect of downregulated $\mathrm{Na}, \mathrm{K}-\mathrm{ATP}$ ase beta1 subunit in alveolar epithelial cells during lung fibrosis. Int J Mol Med 44:273-280. https://doi.org/10.3892/ijmm.2019.4201

Lingrel JB (2010) The physiological significance of the cardiotonic steroid/ouabain-binding site of the Na,K-ATPase. Annu Rev Physiol 72:395-412. https://doi.org/10.1146/annurev-physi ol-021909-135725

Liu J, Kennedy DJ, Yan Y, Shapiro JI (2012) Reactive oxygen species modulation of $\mathrm{Na} / \mathrm{K}$-ATPase regulates fibrosis and renal proximal tubular sodium handling. Int J Nephrol. https://doi.org/10.1155/ 2012/381320

Lubarski-Gotliv I, Asher C, Dada LA, Garty H (2016) FXYD5 protein has a pro-inflammatory role in epithelial cells. J Biol Chem 291:11072-11082. https://doi.org/10.1074/jbc.M115.699041

Lutsenko S, Kaplan JH (1993) An essential role for the extracellular domain of the $\mathrm{Na}, \mathrm{K}$-ATPase beta-subunit in cation occlusion. Biochemistry 32:6737-6743. https://doi.org/10.1021/bi000 $77 \mathrm{a} 029$

Marcus EA et al (2020) Helicobacter pylori infection impairs chaperone-assisted maturation of Na-K-ATPase in gastric epithelium. Am J Physiol Gastrointest Liver Physiol 318:G931-G945. https://doi.org/10.1152/ajpgi.00266.2019

Matsuzaki T et al (2007) Downregulation of organic anion transporters in rat kidney under ischemia/reperfusion-induced acute [corrected] renal failure. Kidney Int 71:539-547. https://doi.org/10. 1038/sj.ki.5002104

Matthay MA et al (2019) Acute respiratory distress syndrome. Nat Rev Dis Prim 5:18. https://doi.org/10.1038/s41572-019-0069-0

Mohan S, Tiwari MN, Biala Y, Yaari Y (2019) Regulation of neuronal $\mathrm{Na}(+) / \mathrm{K}(+)$-ATPase by specific protein kinases and protein phosphatases. J Neurosci 39:5440-5451. https://doi.org/10.1523/ JNEUROSCI.0265-19.2019

Morth JP et al (2009) The structure of the Na+,K+-ATPase and mapping of isoform differences and disease-related mutations. Philos Trans R Soc Lond B Biol Sci 364:217-227. https://doi.org/10. 1098/rstb.2008.0201

Morton MJ, Farr GA, Hull M, Capendeguy O, Horisberger JD, Caplan MJ (2010) Association with \{beta\}-COP regulates the trafficking of the newly synthesized Na,K-ATPase. J Biol Chem 285:3373733746. https://doi.org/10.1074/jbc.M110.141119

Mutlu GM, Sznajder JI (2005) Mechanisms of pulmonary edema clearance. Am J Physiol Lung Cell Mol Physiol 289:L685-695. https://doi.org/10.1152/ajplung.00247.2005

Nyblom $\mathrm{M}$ et al (2013) Crystal structure of $\mathrm{Na}+, \mathrm{K}(+)$-ATPase in the $\mathrm{Na}(+)$-bound state. Science 342:123-127. https://doi.org/10. $1126 /$ science. 1243352

Obradovic M et al (2013) Effects of obesity and estradiol on $\mathrm{Na}+/$ $\mathrm{K}+$-ATPase and their relevance to cardiovascular diseases. J Endocrinol 218:R13-R23. https://doi.org/10.1530/JOE-13-0144

Peteranderl $C$ et al (2019) Influenza a virus infection induces apical redistribution of $\mathrm{Na}(+), \mathrm{K}(+)$-ATPase in lung epithelial cells in vitro and in vivo. Am J Respir Cell Mol Biol 61:395-398. https://doi.org/10.1165/rcmb.2019-0096LE

Peteranderl C et al (2016) Macrophage-epithelial paracrine crosstalk inhibits lung edema clearance during influenza infection. J Clin Invest 126:1566-1580. https://doi.org/10.1172/JCI83931

Poulsen H, Morth P, Egebjerg J, Nissen P (2010) Phosphorylation of the $\mathrm{Na}+, \mathrm{K}+-$ ATPase and the $\mathrm{H}+, \mathrm{K}+$-ATPase. FEBS Lett 584:2589-2595. https://doi.org/10.1016/j.febslet.2010.04.035

Pratscher B et al (2008) Characterization of NKIP: a novel, $\mathrm{Na}+$ / $\mathrm{K}+$-ATPase interacting protein mediates neural differentiation and apoptosis. Exp Cell Res 314:463-477. https://doi.org/10. 1016/j.yexcr.2007.11.013

Pratt RD, Brickman CR, Cottrill CL, Shapiro JI, Liu J (2018) The $\mathrm{Na}$ /K-ATPase signaling: from specific ligands to general reactive oxygen species. Int J Mol Sci 19(9):2600. https://doi.org/ 10.3390/ijms 19092600

Rajasekaran SA et al (2001) Na,K-ATPase activity is required for formation of tight junctions, desmosomes, and induction of polarity in epithelial cells. Mol Biol Cell 12:3717-3732. https://doi. org/10.1091/mbc.12.12.3717

Rajasekaran SA et al (2001) Na,K-ATPase beta-subunit is required for epithelial polarization, suppression of invasion, and cell motility. Mol Biol Cell 12:279-295. https://doi.org/10.1091/ mbc.12.2.279

Rajasekaran SA, Gopal J, Willis D, Espineda C, Twiss JL, Rajasekaran AK (2004) Na,K-ATPase beta1-subunit increases the translation efficiency of the alpha1-subunit in MSV-MDCK cells. Mol Biol Cell 15:3224-3232. https://doi.org/10.1091/mbc.e04-03-0222

Rajasekaran SA, Barwe SP, Rajasekaran AK (2005) Multiple functions of Na, K-ATPase in epithelial cells. Semin Nephrol 25:328-334. https://doi.org/10.1016/j.semnephrol.2005.03.008

Rajasekaran SA, Barwe SP, Gopal J, Ryazantsev S, Schneeberger EE, Rajasekaran AK (2007) Na-K-ATPase regulates tight junction permeability through occludin phosphorylation in pancreatic epithelial cells. Am J Physiol Gastrointest Liver Physiol 292:G124133. https://doi.org/10.1152/ajpgi.00297.2006

Sano R, Reed JC (2013) ER stress-induced cell death mechanisms. Biochim Biophys Acta 1833:3460-3470. https://doi.org/10.1016/j. bbamcr.2013.06.028

Shattock MJ et al (2015) Na+/Ca2+ exchange and Na+/K+-ATPase in the heart. J Physiol 593:1361-1382. https://doi.org/10.1113/ jphysiol.2014.282319

Soltoff SP, Asara JM, Hedden L (2010) Regulation and identification of $\mathrm{Na}, \mathrm{K}$-ATPase alpha1 subunit phosphorylation in rat parotid 
acinar cells. J Biol Chem 285:36330-36338. https://doi.org/10. 1074/jbc.M110.136465

Stabach PR, Devarajan P, Stankewich MC, Bannykh S, Morrow JS (2008) Ankyrin facilitates intracellular trafficking of alpha1$\mathrm{Na}+\mathrm{K}+$-ATPase in polarized cells. Am J Physiol Cell Physiol 295:C1202-C1214. https://doi.org/10.1152/ajpcell.00273.2008

Stanley CM, Gagnon DG, Bernal A, Meyer DJ, Rosenthal JJ, Artigas $\mathrm{P}$ (2015) Importance of the voltage dependence of cardiac $\mathrm{Na} / \mathrm{K}$ ATPase isozymes. Biophys J 109:1852-1862. https://doi.org/10. 1016/j.bpj.2015.09.015

Sune G et al (2010) Cyclophilin B interacts with sodium-potassium ATPase and is required for pump activity in proximal tubule cells of the kidney. PLoS ONE. https://doi.org/10.1371/journal. pone. 0013930

Sweadner KJ, Feschenko MS (2001) Predicted location and limited accessibility of protein kinase a phosphorylation site on $\mathrm{Na}-\mathrm{K}$ ATPase. Am J Physiol Cell Physiol 280:C1017-1026. https://doi. org/10.1152/ajpcell.2001.280.4.C1017

Sweadner KJ, Rael E (2000) The FXYD gene family of small ion transport regulators or channels: cDNA sequence, protein signature sequence, and expression. Genomics 68:41-56. https://doi.org/ 10.1006/geno.2000.6274

Sznajder JI, Factor P, Ingbar DH (2002) Invited review: lung edema clearance: role of $\mathrm{Na}(+)-\mathrm{K}(+)$-ATPase. J Appl Physiol 93:18601866. https://doi.org/10.1152/japplphysiol.00022.2002

Takahashi M, Tsuchiya K, Komatsu Y, Nihei H (1997) A role for Na/K adenosine triphosphatase in the pathogenesis of cyst formation in experimental polycystic kidney disease. J Lab Clin Med 129:517-526. https://doi.org/10.1016/s0022-2143(97)90006-8

Thomson RB, Mentone S, Kim R, Earle K, Delpire E, Somlo S, Aronson PS (2003) Histopathological analysis of renal cystic epithelia in the Pkd2WS25/- mouse model of ADPKD. Am J Physiol Renal Physiol 285:870-880. https://doi.org/10.1152/ajprenal. 00153.2003

Tian J, Xie ZJ (2008) The Na-K-ATPase and calcium-signaling microdomains. Physiology 23:205-211. https://doi.org/10.1152/physi ol.00008.2008

Tokhtaeva E et al (2016) The O-glycosylated ectodomain of FXYD5 impairs adhesion by disrupting cell-cell trans-dimerization of Na,K-ATPase beta1 subunits. J Cell Sci 129:2394-2406. https:// doi.org/10.1242/jcs. 186148

Tokhtaeva E, Sachs G, Vagin O (2009) Assembly with the Na,KATPase alpha(1) subunit is required for export of beta(1) and beta(2) subunits from the endoplasmic reticulum. Biochemistry 48:11421-11431. https://doi.org/10.1021/bi901438z

Tokhtaeva E, Munson K, Sachs G, Vagin O (2010) N-glycan-dependent quality control of the Na,K-ATPase beta(2) subunit. Biochemistry 49:3116-3128. https://doi.org/10.1021/bi100115a

Tokhtaeva E, Sachs G, Vagin O (2010) Diverse pathways for maturation of the Na,K-ATPase beta1 and beta2 subunits in the endoplasmic reticulum of Madin-Darby canine kidney cells. J Biol Chem 285:39289-39302. https://doi.org/10.1074/jbc.M110. 172858

Tokhtaeva E, Sachs G, Souda P, Bassilian S, Whitelegge JP, Shoshani L, Vagin O (2011) Epithelial junctions depend on intercellular trans-interactions between the Na,K-ATPase beta(1) subunits. J Biol Chem 286:25801-25812. https://doi.org/10.1074/jbc.M111. 252247

Tokhtaeva E, Sachs G, Sun H, Dada LA, Sznajder JI, Vagin O (2012) Identification of the amino acid region involved in the intercellular interaction between the betal subunits of $\mathrm{Na}+\mathrm{K}+-$ ATPase. J Cell Sci 125:1605-1616. https://doi.org/10.1242/jcs.100149

Turner MJ et al (2016) Hypercapnia modulates cAMP signalling and cystic fibrosis transmembrane conductance regulator-dependent anion and fluid secretion in airway epithelia. J Physiol 594:16431661. https://doi.org/10.1113/JP271309

Vadasz I et al (2012) Evolutionary conserved role of c-Jun-N-terminal kinase in CO2-induced epithelial dysfunction. PLoS One 7:e46696. https://doi.org/10.1371/journal.pone.0046696

Vadasz I, Raviv S, Sznajder JI (2007) Alveolar epithelium and Na,KATPase in acute lung injury. Intensive Care Med 33:1243-1251. https://doi.org/10.1007/s00134-007-0661-8

Vadasz I et al (2008) AMP-activated protein kinase regulates CO2induced alveolar epithelial dysfunction in rats and human cells by promoting Na,K-ATPase Endocytosis. J Clin Invest 118:752762. https://doi.org/10.1172/JCI29723

Vadasz I, Hubmayr RD, Nin N, Sporn PH, Sznajder JI (2012) Hypercapnia: a nonpermissive environment for the lung. Am J Respir Cell Mol Biol 46:417-421. https://doi.org/10.1165/rcmb. 2011-0395PS

Vagin O, Tokhtaeva E, Sachs G (2006) The role of the beta1 subunit of the Na,K-ATPase and its glycosylation in cell-cell adhesion. J Biol Chem 281:39573-39587. https://doi.org/10.1074/jbc. M606507200

Vagin O, Tokhtaeva E, Yakubov I, Shevchenko E, Sachs G (2008) Inverse correlation between the extent of $\mathrm{N}$-glycan branching and intercellular adhesion in epithelia. Contribution of the $\mathrm{Na}$, K-ATPase beta1 subunit. J Biol Chem 283:2192-2202. https:// doi.org/10.1074/jbc.M704713200

Vagin O, Dada LA, Tokhtaeva E, Sachs G (2012) The Na-K-ATPase alpha(1)beta(1) heterodimer as a cell adhesion molecule in epithelia. Am J Physiol Cell Physiol 302:C1271-C1281. https://doi. org/10.1152/ajpcell.00456.2011

Vague P, Coste TC, Jannot MF, Raccah D, Tsimaratos M (2004) C-peptide, $\mathrm{Na}+, \mathrm{K}(+)$-ATPase, and diabetes. Exp Diabesity Res 5:37-50. https://doi.org/10.1080/15438600490424514

Wang M, Kaufman RJ (2016) Protein misfolding in the endoplasmic reticulum as a conduit to human disease. Nature 529:326-335. https://doi.org/10.1038/nature17041

Welch LC, Lecuona E, Briva A, Trejo HE, Dada LA, Sznajder JI (2010) Extracellular signal-regulated kinase (ERK) participates in the hypercapnia-induced Na,K-ATPase downregulation. FEBS Lett 584:3985-3989. https://doi.org/10.1016/j.febslet.2010.08.002

Wieser W, Krumschnabel G (2001) Hierarchies of ATP-consuming processes: direct compared with indirect measurements, and comparative aspects. Biochem J 355:389-395. https://doi.org/ 10.1042/0264-6021:3550389

Wilson PD et al (2000) Apical plasma membrane mispolarization of NaK-ATPase in polycystic kidney disease epithelia is associated with aberrant expression of the beta2 isoform. Am J Pathol 156:253-268. https://doi.org/10.1016/s0002-9440(10)64726-8

Yordy MR, Bowen JW (1993) Na,K-ATPase expression and cell volume during hypertonic stress in human renal cells. Kidney Int 43:940-948. https://doi.org/10.1038/ki.1993.132

Zatti A, Chauvet V, Rajendran V, Kimura T, Pagel P, Caplan MJ (2005) The C-terminal tail of the polycystin-1 protein interacts with the Na,K-ATPase alpha-subunit. Mol Biol Cell 16:5087-5093. https://doi.org/10.1091/mbc.e05-03-0200

Zatyka M et al (2008) Sodium-potassium ATPase 1 subunit is a molecular partner of Wolframin, an endoplasmic reticulum protein involved in ER stress. Hum Mol Genet 17:190-200. https://doi. org/10.1093/hmg/ddm296

Publisher's Note Springer Nature remains neutral with regard to jurisdictional claims in published maps and institutional affiliations. 